\title{
The excavation, conservation and reconstruction of Lapita burial pots from the Teouma site, Efate, Central Vanuatu
}

\author{
Stuart Bedford', Matthew Spriggs², Ralph Regenvanu³, Colin Macgregor ${ }^{4}$, \\ Takaronga Kuautonga ${ }^{3}$ and Michael Sietz ${ }^{4}$

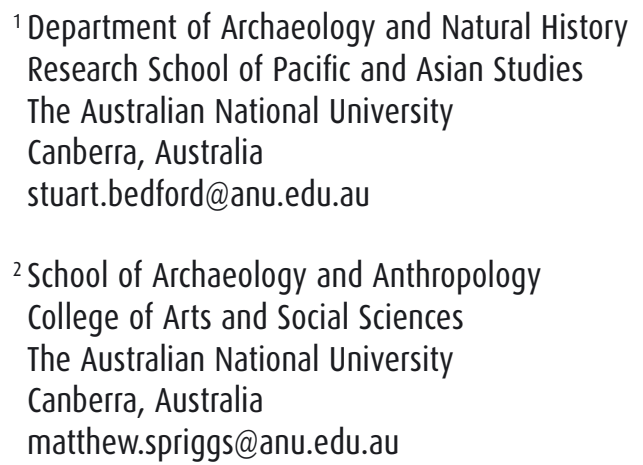 \\ ${ }^{3}$ Vanuatu Cultural Centre \\ P.0. Box 184, Port Vila, Vanuatu \\ ralph.regenvanu@vanuatuculture.org \\ ${ }^{4}$ Australian Museum \\ Sydney, NSW 2010, Australia \\ colin.macgregor@austmus.gov.au
}

\section{Introduction}

The recovery of complete Lapita pots is an extreme rarity. Of the over two hundred sites so far identified across the Lapita spectrum and particularly those sites associated with the earlier phase of the pottery sequence, discoveries have to date largely been restricted to the eponymous site of Lapita in New Caledonia (Coote and Sand 1999; Sand 1996, 1999, 2000; Sand et al. 1998). At that site, within a pit feature, two whole pots had been buried on top of and beneath large sherds of other pots. Their excavation and conservation ultimately led to detailed reconstruction of eleven pots, providing a major impetus to the characterisation of the New Caledonian Lapita ceramic repertoire. Up to three further complete carinated vessels from the same site have been more recently discovered and are still undergoing conservation treatment (Sand pers. comm.). A whole collection of reconstructable late Lapita vessels have also been recovered from the Sigatoka sand dunes over many decades (Birks 1973; Burley and Dickinson 2004). In January 2004 the Teouma Lapita site was discovered on the southeast coast of Efate, Vanuatu (Bedford et al. 2004; 2006). Three field seasons at the site have enabled the identification of an extensive Lapita cemetery with almost 50 burials. Associated with some of these burials were a number of fragmented but complete decorated Lapita pots, including four carinated vessels and a flat- 


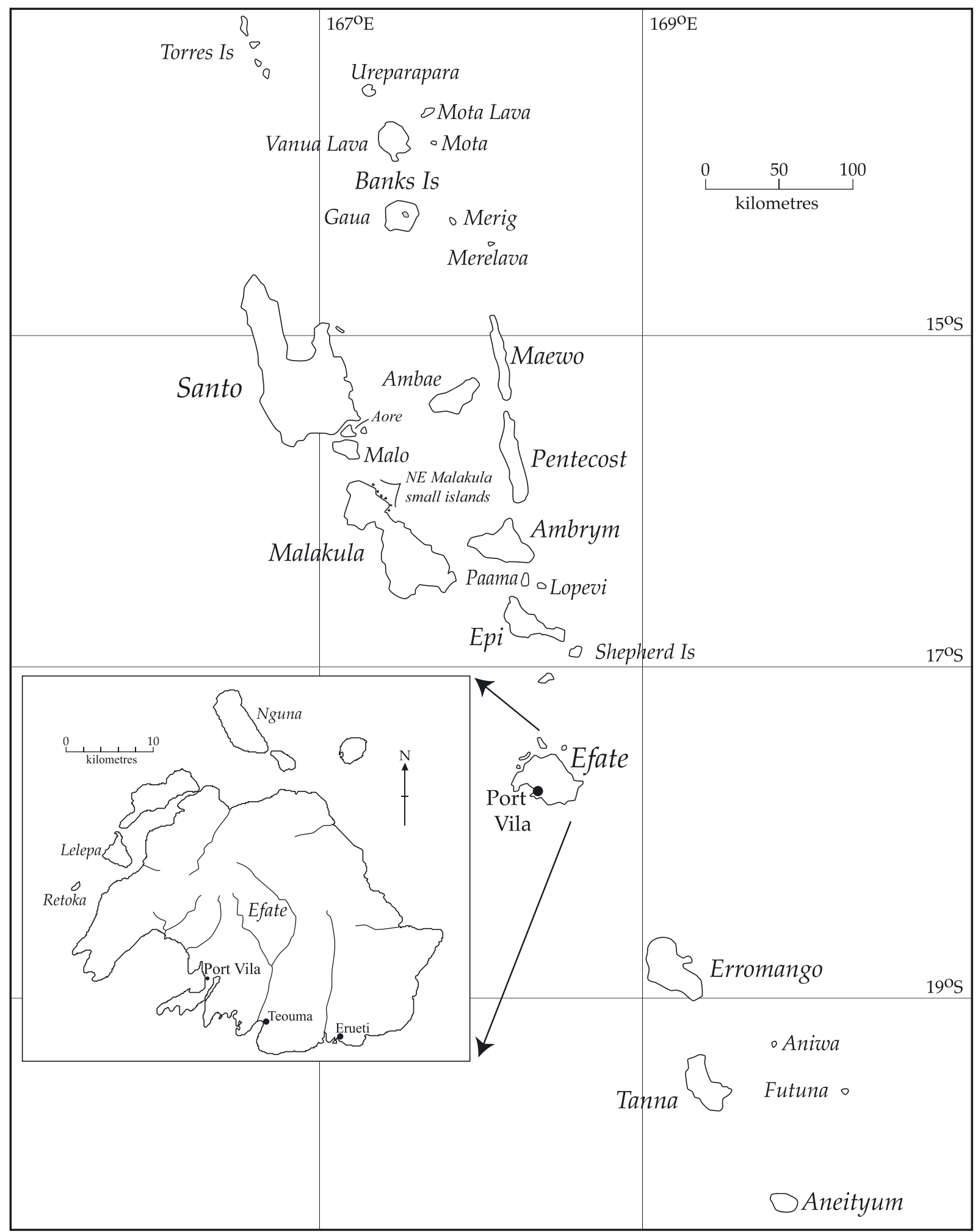

Figure 1. Teouma, Efate, Vanuatu. 
bottomed dish. A complete undecorated pot stand has also been recovered. Following their excavation, they were conserved and reconstructed at the Australian Museum. This discovery provides a rare opportunity to profile these decorated pots that were linked to mortuary practice.

\section{Excavation and recovery}

The Teouma Lapita site is located $800 \mathrm{~m}$ from the sea, on the edge of an upraised former beach terrace and reef some eight metres above current sea level, on the north eastern side of Teouma Bay, southeast Efate (Figure 1). The site sits on top of a former rolled-coral upper beach and uplifted karstic reef terrace. Just prior to the arrival of colonising communities on Efate a thick layer of tephra was deposited across the uplifted terrace. When people did arrive, the site would have been located on a low promontory bounded by the sea on its western side and the small stream on its northeast side. The largely unweathered orange/yellow tephra that had been deposited prior to human arrival created a level surface across the craggy uplifted reef. The primary use of the area was as a cemetery where burials were placed in shallow graves dug into the tephra in gaps in the uplifted reef and the former upper beach area. Subsequent to the site being used as a cemetery, some $50 \mathrm{~cm}$ of midden was deposited across the site as a result of habitation activities, which in turn was later sealed by further tephra deposits (Bedford et al. 2004; 2006).

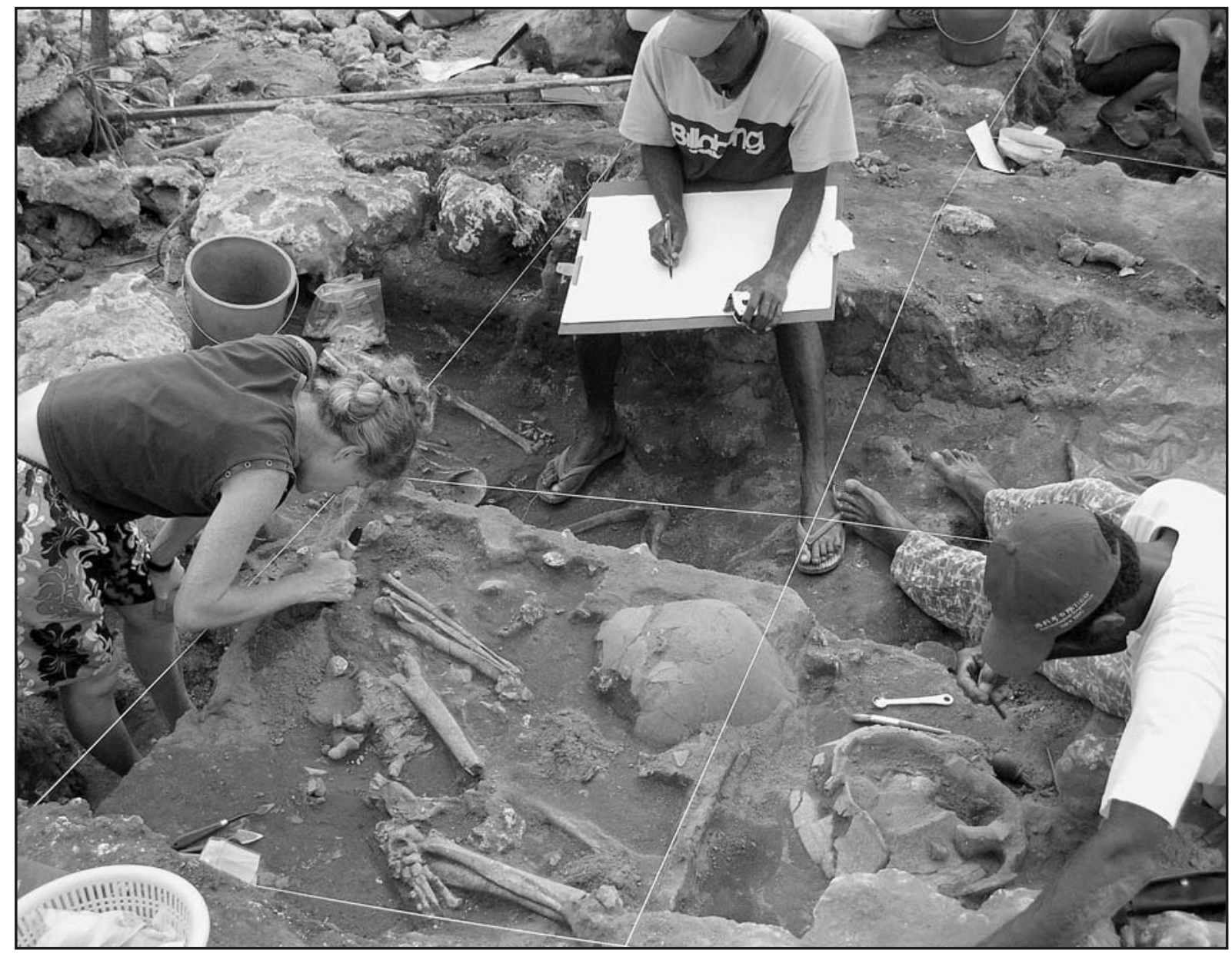

Figure 2. Excavation of the Teouma cemetery, 2005. Upturned Pot 3 is in the centre and Pot 2 with skull is on the right (the flatbottomed dish has been removed). Excavators are Frédérique Valentin and jacques Bolé. Fidel Yoringmal is the illustrator. 
There is evidence across much of the cemetery that decorated Lapita pots were intimately connected with mortuary practice at the site. However, as is the case with the burials themselves, there is no standard or regular pattern that is apparent with the placement or use of the pots associated with the burials. Many of the pots had been disturbed during the use of the site for burial and in many cases concentrations of sherds of a single pot were found across one or two square metres. There were several instances of pot bases containing assorted human bone being recorded in situ and associated upper parts of the pot being scattered nearby (Bedford and Spriggs 2007). This suggested that these particular pots had been buried only up to the carination and/or subsequent activity had disturbed the upper decorated section.

Three of the complete pots discussed here (Pot 2 and 3 and the flat-bottomed dish) were concentrated amongst a cluster of burials interred within the tephra matrix in a solution hole in the former reef (Figure 2). Grave cuts and or other cut features contemporary with activity at the cemetery were extremely difficult to identify as they were being cut into and filled with the same undifferentiated tephra. There was little evidence for weathering or other deposits in the area where the pots were recovered. The pots appear to have been buried after being placed near burials as they are surrounded and sealed by the undifferentiated tephra. This concentration of burials and pots was also somewhat protected by a combination of depth of tephra and the surrounding remnant uplifted reef. This was dramatically emphasised when teeth marks from a mechanical excavator were found carved into a section of the adjacent remnant reef some $100 \mathrm{~mm}$ above the flat-bottomed dish.

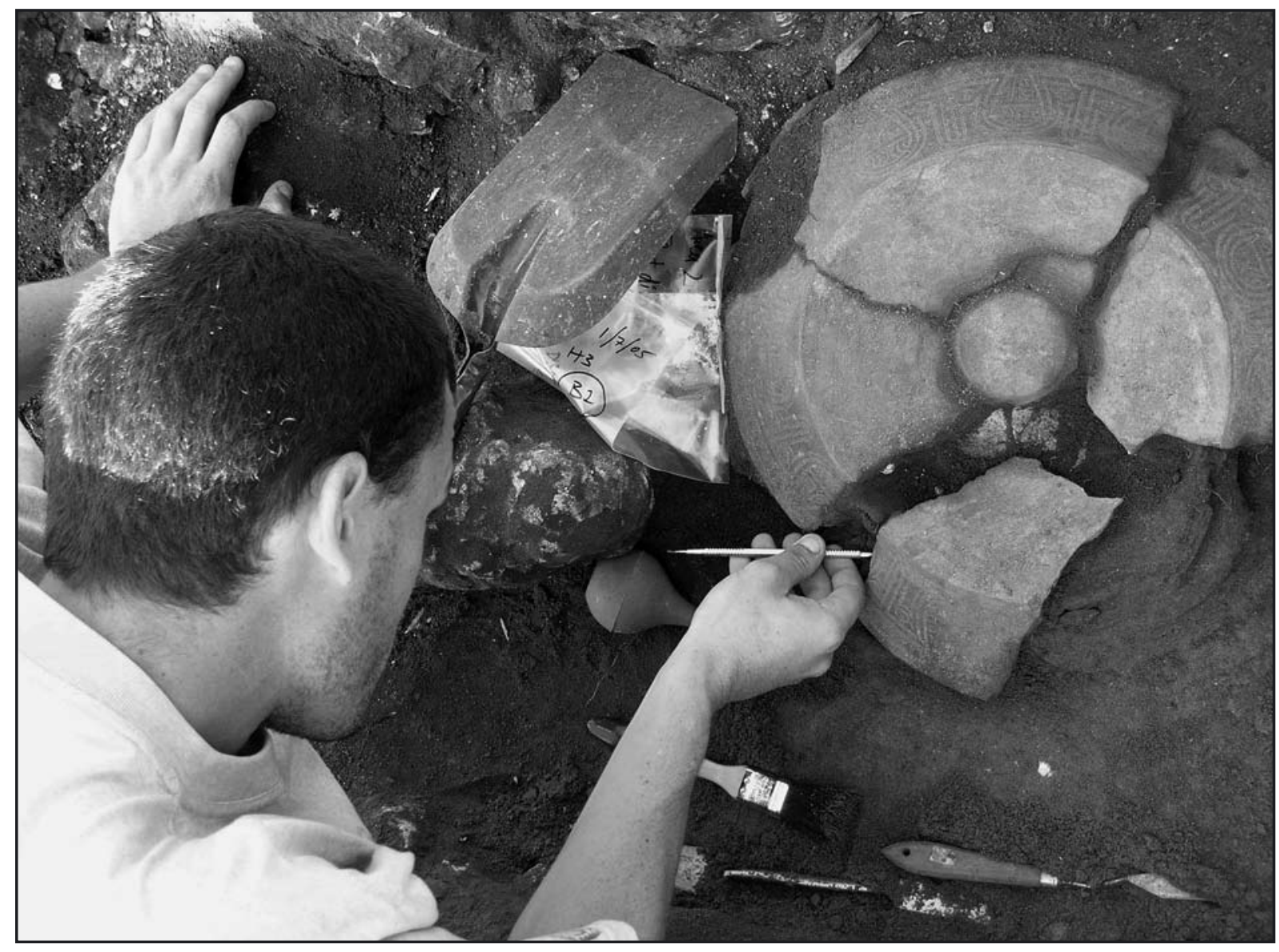

Figure 3. Flat-bottomed dish being removed piece by piece. Excavator is Andrew Hoffman. Note both the top of the skull (centre of the dish) and the rim of Pot 2 can also be seen (bottom right of dish). 
Although the chronology and other specifics of mortuary practice at the site including pottery associations will be discussed in detail in a subsequent publication, some general context relating to the complete pots is provided here. Sherds from Pot 1 were simply surface collected by workmen following mechanical earthmoving and quarrying at the site. Pot 2, a carinated vessel, contained a complete skull that sat on top of a broken Conus sp. ring. The flat-bottomed dish had been turned upside down and placed directly on top of Pot 2, acting as a lid (Figure 3). Most of Pot 2 is very thin walled, generally only $5 \mathrm{~mm}$ thick except for the carination area where it is some $15 \mathrm{~mm}$ thick. The pot had primarily broken at the carination and collapsed in onto the skull. The nature of this breakage indicates that once the skull had been placed in the pot it was not infilled with soil prior to the placement of the flat-bottomed dish. A lack of extra support that would have been supplied by a fill, combined with the added weight of the dish and subsequent infill, encouraged collapse (Figure 4). Pot 3 , another carinated vessel, situated adjacent to Pot 2 and the dish, was found inverted and sitting on its rim. Some collapse had also occurred in the carination area but generally the pot had retained much of its original structural form, indicating that the pot must have been fully buried after placement (Figure 5).

Pot 4 was recovered during excavations in 2006. Another carinated vessel, it had been buried in the upper beach deposits adjacent to a number of burials. Later activity on the site, in the form of a large posthole associated with the later midden layer, had partly damaged the pot. Structural failure had occurred in the carination area, with the lower part of the neck shifting inwards while the upper part of the pot collapsed outward (Figure 6). This suggests that the upper part of the pot may not have been buried immediately after

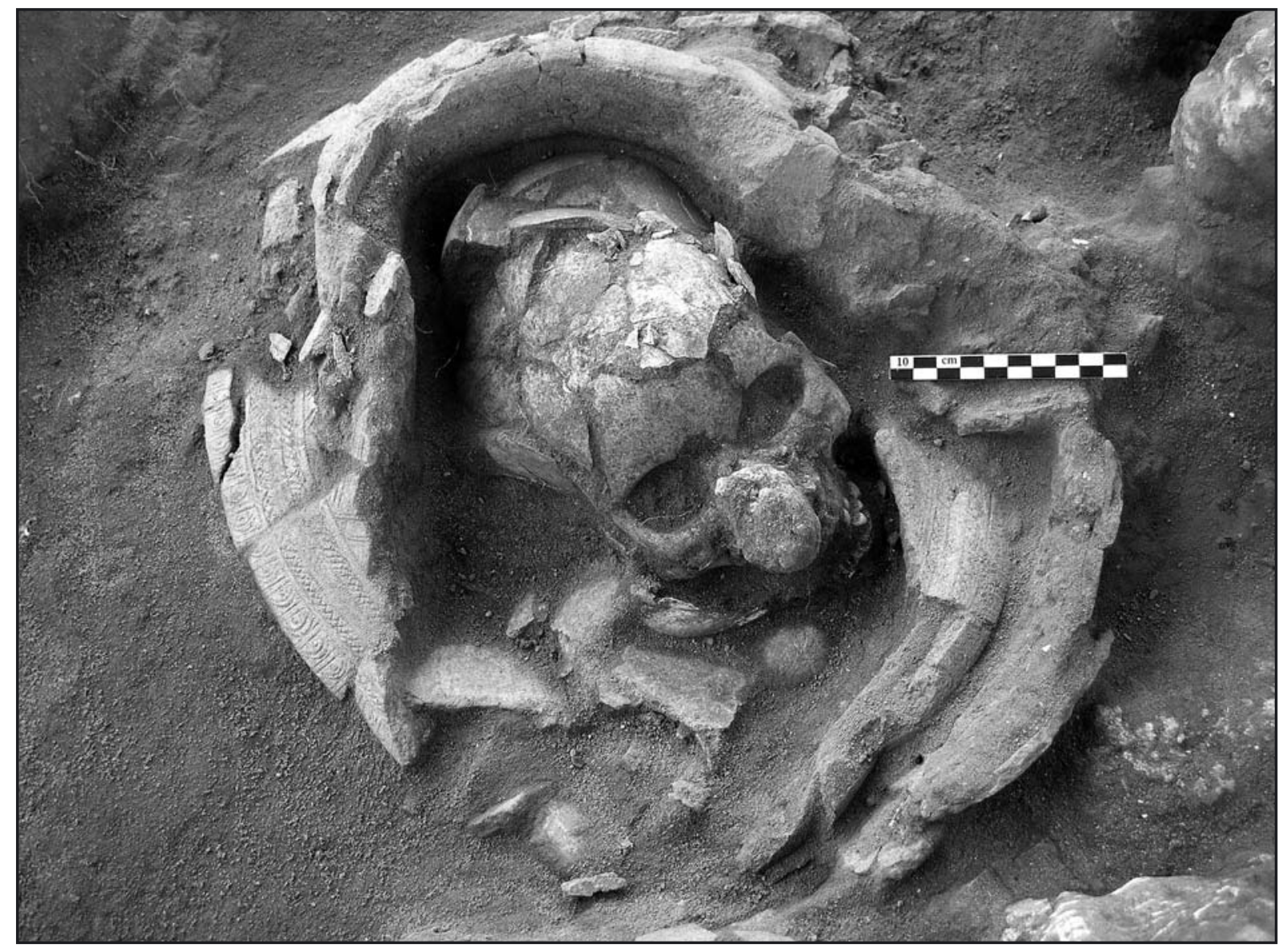

Figure 4. Pot 2 which had broken at the carination and collapsed inward. 


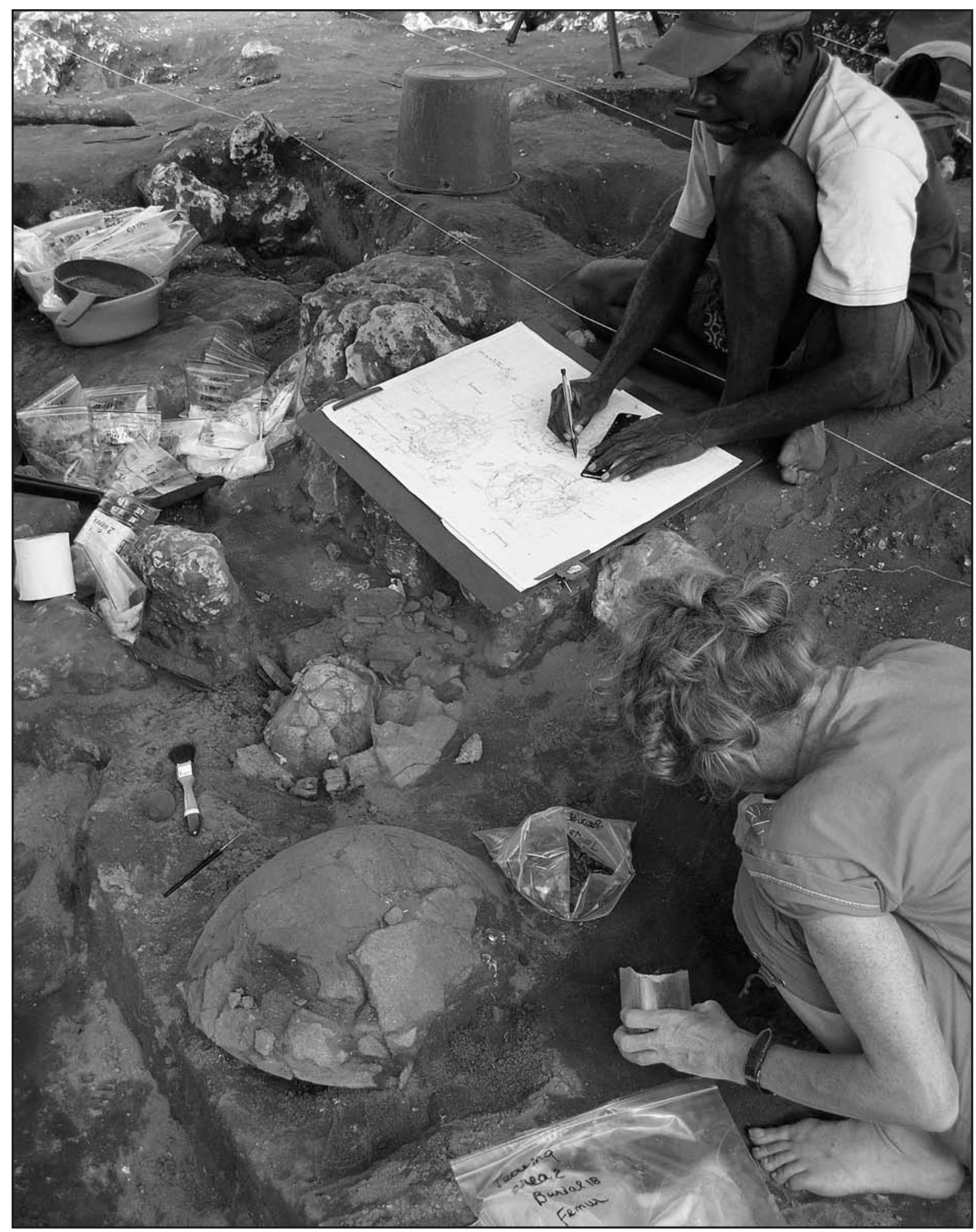

Figure 5. Pot 3 in the foreground with globular base and part of the carination exposed. In the centre is Pot 2 (much of which has been removed) with the skull exposed.

its deposition. A concentration of very small Cypraea sp. shells was found in the base of the pot. The plain pot stand was also found in 2006, lying on its side adjacent to several burials. It seems likely to have been associated with mortuary activities but found somewhat removed from its original context. It was largely intact apart from a section near the rim. Following an on-site assessment by Colin Mcgregor and Takaronga 
Kuautonga it was decided that due to its robust and intact nature, its conservation and reconstruction could be carried out in Port Vila.

On-site recording of the pots was undertaken with both a photographic record and illustrations. The excavated vessels were lifted and bagged on site after the layout of fragments was accurately drawn onto plans. These plans and photos were essential in facilitating the later reconstruction process.

\section{Description of pots}

The well-preserved pottery remains from the Teouma cemetery and midden dumping deposits will ultimately provide a detailed profile of Lapita vessel forms and decorative motifs which up until now has been completely lacking from Central Vanuatu. It will also provide a robust data set with which to make wider comparisons with more complete collections (Bedford and Spriggs in prep). In this paper we focus only on the five most complete pots and pot stand that were clearly in association with mortuary practice and have been discussed above. As noted five of these vessels were excavated in situ (Pots 2-4, flat-bottomed dish and pot stand) and another collected from bulldozed deposits (Pot 1). Description of design motifs and zone markers follows that of Donovan (1973) where applicable.

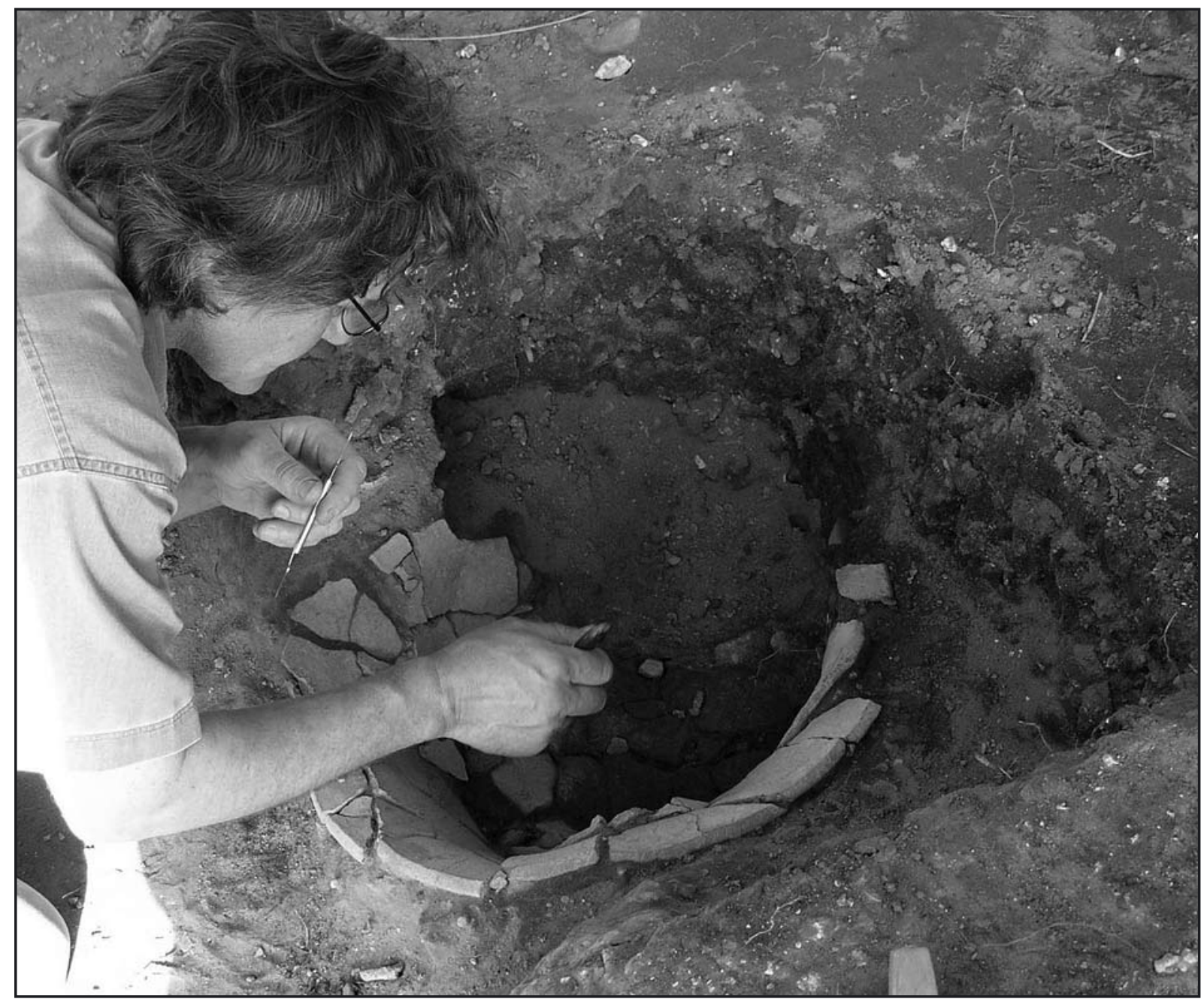

Figure 6. Pot 4 showing neck and rim splayed outward. Excavator is Colin Macgregor. 


\section{Pot No. 1 Carinated vessel with flat base}

Dimensions: full height: $215 \mathrm{~mm}$, carination to the base: $90 \mathrm{~mm}$, diameter: $310 \mathrm{~mm}$, thickness: $5-10 \mathrm{~mm}$ (Figure 7).

It is this pot that lay at the centre of a whole series of serendipitous coincidences that led to the discovery of the site. A single large dentate-stamped sherd from this pot was the key to finding the site (Bedford et al. 2004) but the subsequent recovery of a dozen other sherds from the same vessel, ultimately some $75 \%$ of the whole vessel which enabled a full reconstruction of the pot, were equally opportune and unexpected. Prior to earthworks at the site this pot was almost certainly complete although fragmented as indicated by weathered breaks on most sherds. This contrasted with several fresh breaks inflicted during the earthmoving activities. There was no stratigraphic context for this pot apart from the fact that it was retrieved from the Lapita deposits during quarrying. At the start of excavations in 2004 further sherds of this vessel were donated by Madame Monvoisin, the leaseholder of the land on which the site is located, who had retrieved them along with a number of other sherds, from a workshop situated on the farm.

Reconstruction of the pot began at the start of 2006 and at the same time further sherds, which had been collected while the site was being bulldozed, were donated from nearby Eratap village. News also came back from Sydney that suggested the base of the pot was flat rather than rounded. A search through a selection of unusual plain sherds that could not earlier be assigned to any vessel form revealed sections of the base. This distinctive vessel form is a first for Vanuatu and there do not appear to be any further examples at Teouma. One example only of this form of flat-bottomed carinated vessel has been identified in New Caledonia (Christophe Sand pers. comm.) suggesting that it is vary rare generally, although in the case of some sites this may be partly due to poor sherd preservation and an inability to securely define vessel form.

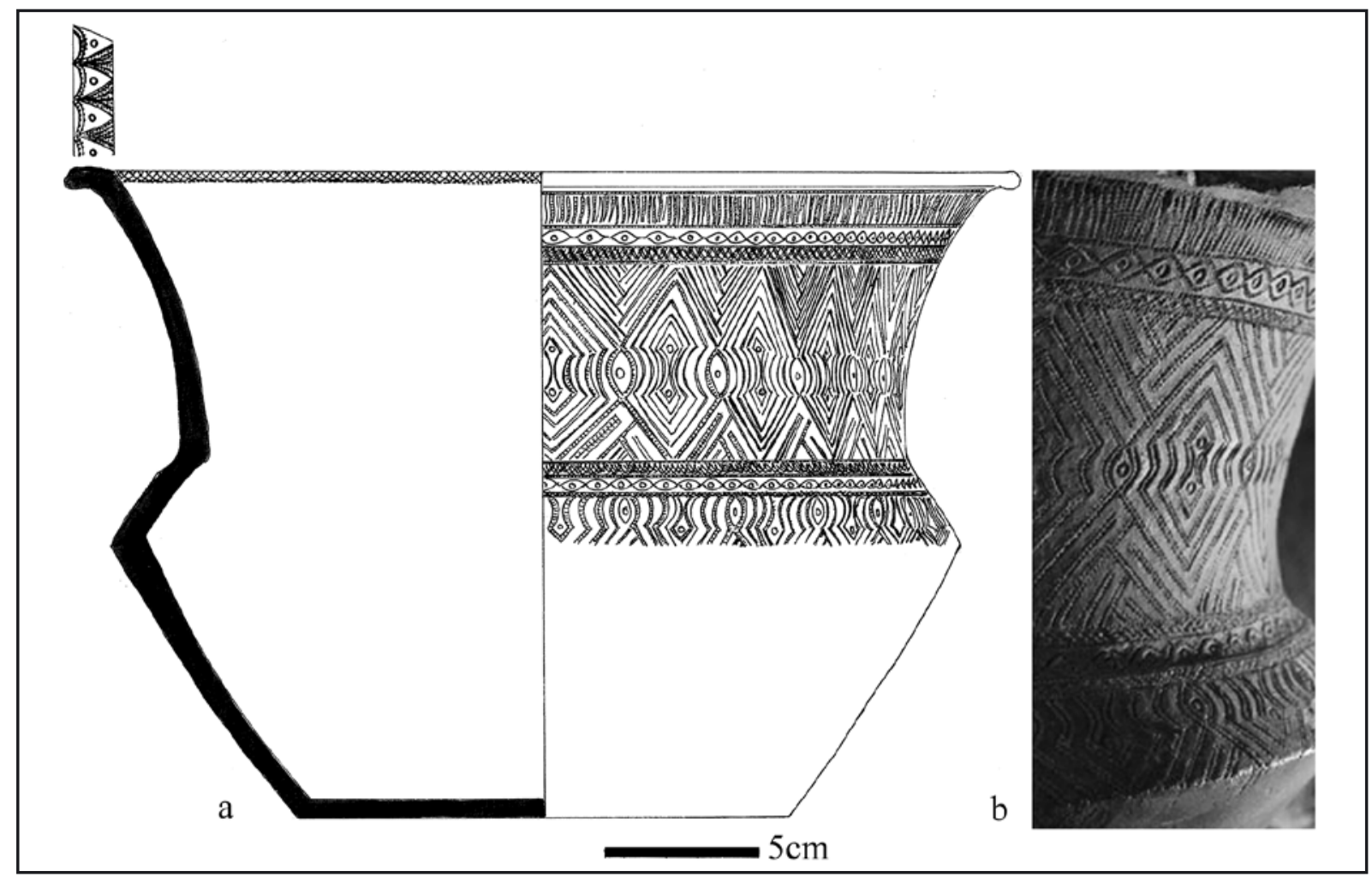

Figure 7. a. Pot 1 form and decoration and b. photograph of full motif. 
The pot itself is very robust and finely decorated with a strongly flaring rim that is wider in circumference than the carination area. The neck region of the pot where the bulk of the decoration is situated is $65 \mathrm{~mm}$ in width. From the top of the pot downwards the dentate design is as follows. The interior rim is decorated with a restricted zone marker (RZ 3) and on the wide flat rim with M19.14. The design on the neck of the pot is bounded by a transverse zone marker, M28.3 and below that M5.6. The central band or frieze is a variant of M13(2).5 (bounded by a restricted zone marker [RZ 3]) with M5.6 repeated below that. The lowest band of decoration (separated from M5.6 by a further restricted zone marker [RZ 3]), situated on the upper part of the carination proper is a variant of M14(2).7.

Illustration of these pots was commenced in 2005 prior to their reconstruction and when they were returned to the Vanuatu Cultural Centre in 2006 the drawings were rechecked. Generally minimum modification was required but the hazards of speculation or assumption when dealing with fragmentary collections was highlighted when the flat base of Pot 1 was revealed. It had already been incorrectly published as having a curved base (Bedford et al. 2006: Fig.7).

\section{Pot No. 2 Carinated vessel}

Dimensions: full height: $245 \mathrm{~mm}$, carination to base: $137 \mathrm{~mm}$, diameter: $324 \mathrm{~mm}$, thickness: 5-15 mm (Figure 8).

Some ninety per cent of this carinated vessel was preserved but it was one of the more fragmented, comprising almost 200 separate sherds. As outlined, this may have been due to the combined factors of poor vessel robusticity, position and the added weight of the flat-bottomed dish as a lid. Decoration on the inner rim of this vessel comprise a restricted zone marker (RZ 4) and on the wide flat rim M19.14, in this instance in mirror image to that seen on Pot 1. A restricted zone marker (RZ 4) runs around the circumference of the upper part of the rim and below this, the central frieze is made up of a variant of M13. Below that there are two restricted zone markers (RZ 4) one above the other. Below these, on the upper part of the carination proper is a variant of M59. The neck is more curved and restricted in its width $(59 \mathrm{~mm})$ than the other carinated vessels at the site. The dentate-stamping tends to be coarsely applied and the central frieze design is expanded (Figure 9).

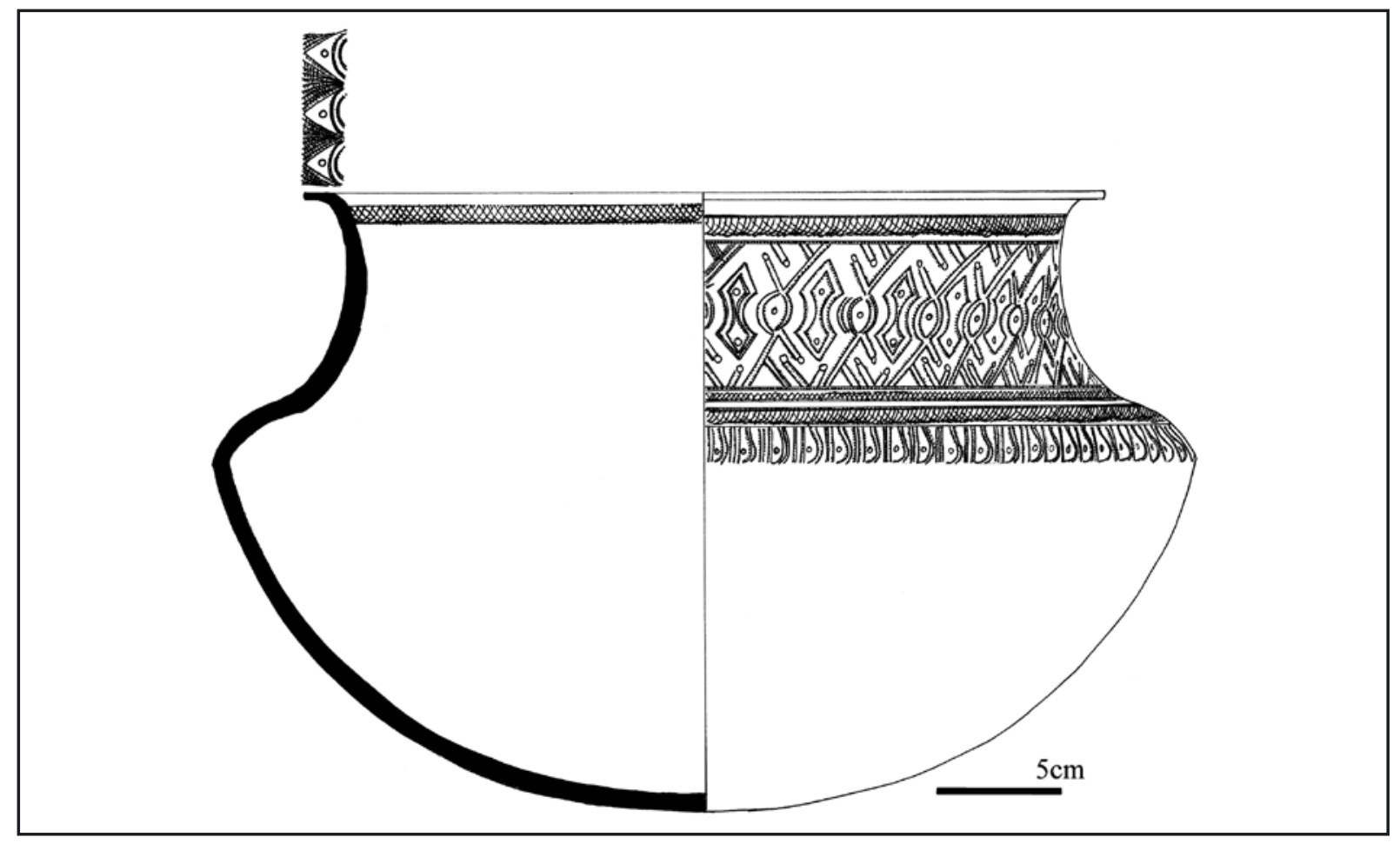

Figure 8. Pot 2 form and decoration. 


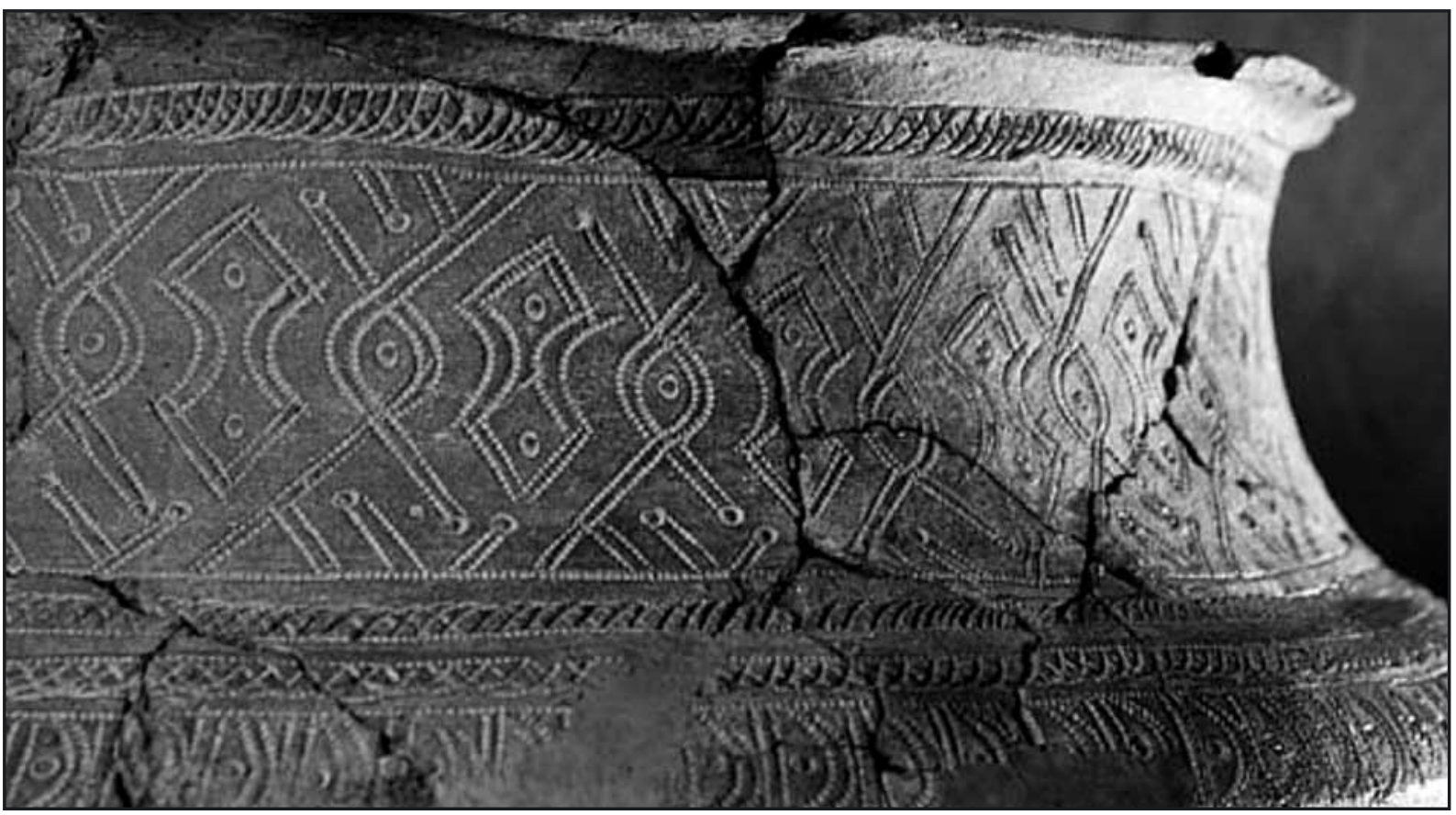

Figure 9. Close up of Pot 2 decoration.

\section{Pot No. 3 Carinated vessel}

Dimensions: full height: $400 \mathrm{~mm}$, carination to base: $210 \mathrm{~mm}$, diameter: $450 \mathrm{~mm}$, thickness 5-8 mm (Figure 10).

This is one of the two largest recovered pots, coming close in overall size to the largest carinated vessels found in New Caledonia (Clark this volume; Sand et al. 1998). There is no decoration on the inner rim. The lip is decorated with M77.4. The uppermost decoration below the lip is a zone marker followed by a restricted zone marker (RZ 4). The primary decoration on the neck ( $95 \mathrm{~mm}$ wide) of the vessel, the central frieze, is a distinctive geometrical motif that has elements of both M100 and M27 and is bounded by zone markers. Below this a further restricted zone marker (RZ 4) completing the decoration of the neck. On the upper part of the carination is M1.6 in mirror image bounded on the lower side by a further zone marker (RZ 4). Motif M19.7 completes the lower part of the design just on the edge of the upper part of the carination. The dentate on this vessel tends to be less fine and the central frieze design, as in the case of Pot 2, is expanded or exploded rather than being compactly formatted.

\section{Pot No. 4 Carinated vessel}

Dimensions: full height: c. $340 \mathrm{~mm}$, carination to base:115mm, diameter: $550 \mathrm{~mm}$, thickness: $5-10 \mathrm{~mm}$ (Figure 11).

This fourth carinated vessel excavated in 2006 has also recently been conserved and reconstructed by the Australian Museum. While detailed measurements were taken on a series of large sherds prior to it being sent to Sydney, the final reconstruction has provided greatly enhanced accuracy. It is, along with Pot 3, one of the two largest carinated vessels recovered from the site. There is no decoration on the inner rim. Decoration from the top down commences on the wide flat lip with M14(2).4. Just below the lip, the upper most decoration is a restricted zone marker (RZ 4) followed by a dentate version of M6.1. The primary decoration on the neck of the vessel, the central frieze, is a labyrinth design similar to M73 but without any additional motifs. The width of the central band design is $125 \mathrm{~mm}$. It is bordered by restricted zone markers (RZ 4). Below that is M5.6 separated from the motif decorating the upper part of the carination by a repeat of RZ4. The lowest motif, which is not listed in Donovan but might be seen as a variant of M14(2).10, comprises what can be simply described as a series of interlocking concentric carinated vessel forms (labelled by Sand as interlocking triangles [Sand 1999:57]) interrupted by two sets (on opposite sides of the pot) of three vertical nubbins or lugs. In between the lugs are singular versions of the concentric carinated vessel form. 


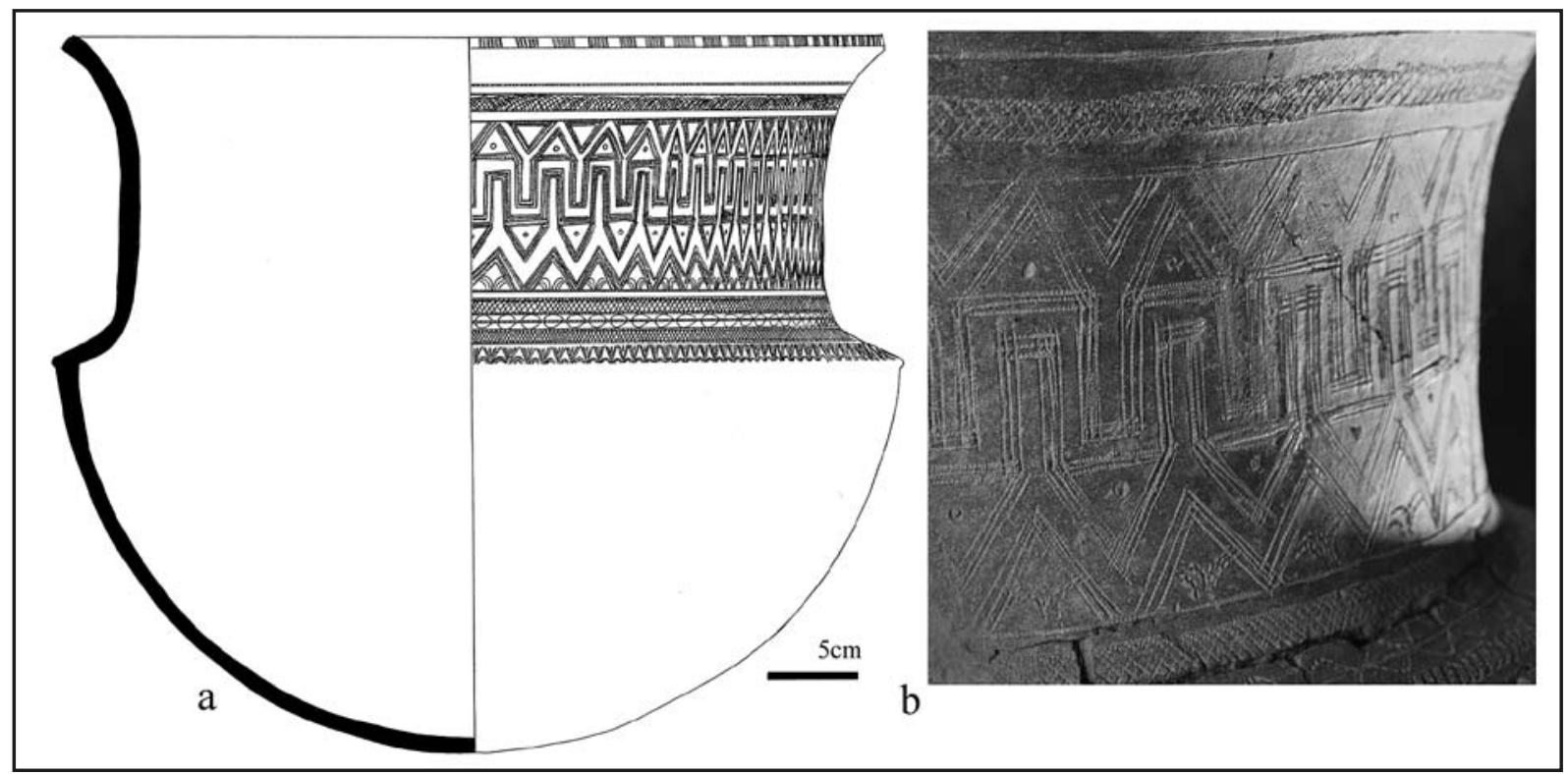

Figure 10. a. Pot 3 form and decoration and b. photograph of central frieze.

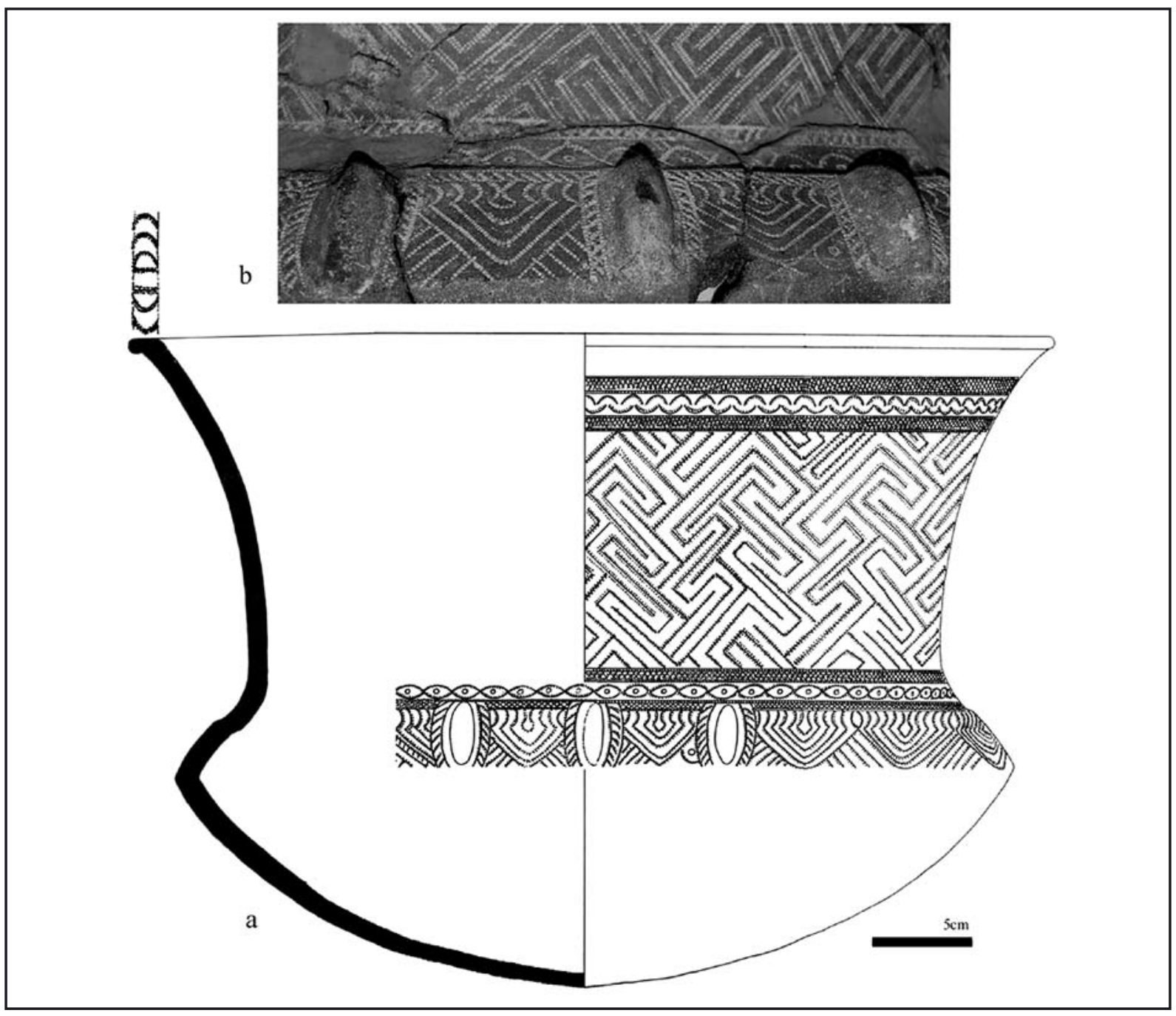

Figure 11. a. Pot 4 form and decoration and b. closeup of lugs or nubbins. 
In the field it was difficult to determine whether the base was flat or curved due to its crushed nature. Once reconstructed, however, it could be firmly established that the vessel in fact has a very shallow base (115 $\mathrm{mm}$ from carination to base). This is a particularly distinctive feature of this vessel which has the effect of further emphasising the central frieze.

\section{Flat-bottomed dish}

Dimensions: height: $70 \mathrm{~mm}$, diameter: $360 \mathrm{~mm}$, thickness 9-12 mm thick (Figures 12, 13).

The flat-bottomed dish is a relatively robust vessel with generally thicker walls and base. A total of 12 sherds were recovered which comprised $95 \%$ of the vessel. The dish has a circular groove $(9.5 \mathrm{~mm}$ in diameter) in the centre of its base, a strong indication that it was originally made to sit on top of a cylinder stand. Several of these stands have been identified amongst the recovered materials. This is further emphasised with the strongly flaring nature of the rim, where without elevation, the full design is to some extent obscured. The only decoration on the interior rim is a restricted zone marker (RZ 3). The lip is decorated with a variant of Motif 19 combining a row of impressed circles (nearest the interior) and a curved version of M19.1. Restricted zone markers (RZ 3) run the full circumference of the dish just below the lip and also just above the base. Just below the upper restricted zone marker M19 is found encircling the dish, although interrupted at various points where an inverted face motif is found. The decoration of the dish is dominated by a double face motif that is replicated around the full circumference of the dish, the joining point of which is facilitated by an extra 'nose' infilled with impressed circles (Figure 13).

Double face motifs have been noted further west and in New Caledonia (Chiu 2005; Sand 1996; Spriggs 1990:93, 1993, 2002) but are always set within a single design, one above the other. The alternating double face motif found on the Teouma dish is thus far unique, although its uniqueness may be simply related to the fragmentary nature of most Lapita sherd collections (see Chiu this volume). The alternating double face motif might be seen as an adaptation of the other double face motifs where the triangular face with a semicircular cap is often a central feature. This motif is also found singularly (Chiu 2005:28; Sand 1999:54) although again the fragmentary nature of collections often makes assessment of this difficult. The inverted triangular face is combined with the 'long nose' or 'elongated face' motif (Sand 1999:55), a motif that has again been recorded across much of the Lapita distribution (Chiu 2005; Spriggs 1990, 1993). Given restrictions of space on the vessel, the triangular face has been flipped and placed adjacent to the elongated face motif. In many respects the motif is very similar structurally to the elongated face motifs with 'earplugs'. The 'earplugs' in this case, however, have been replaced with inverted triangular faces. The dentate-stamping on this dish is fine and the motif is tightly structured.

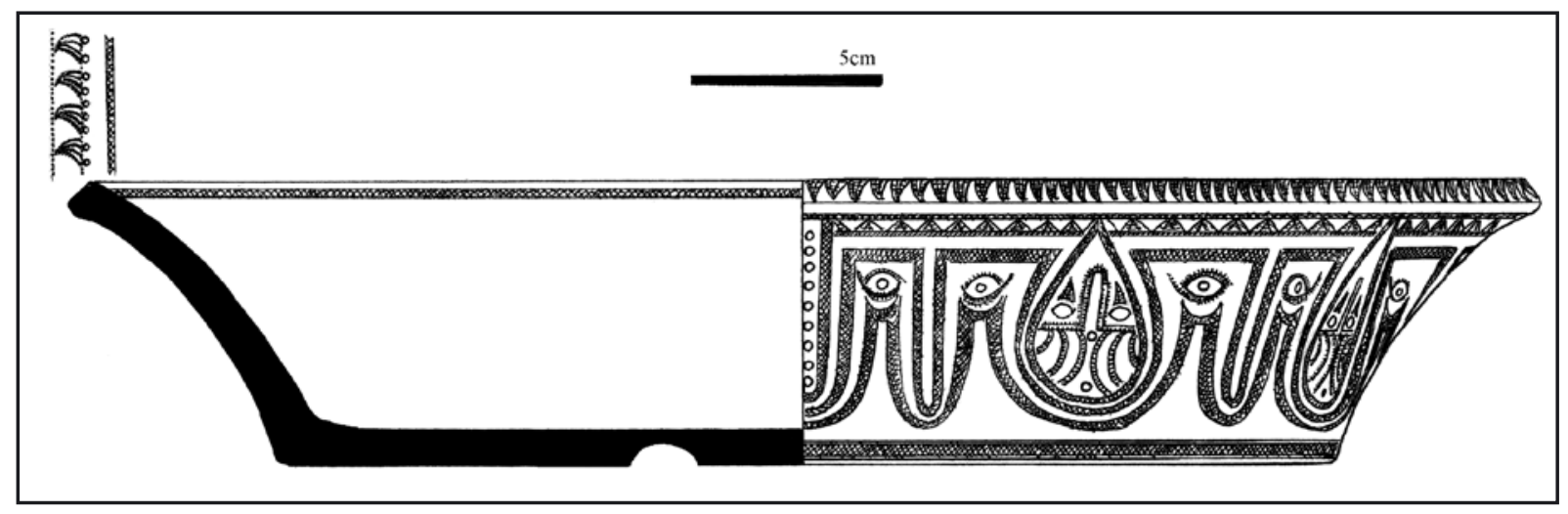

Figure 12. Flat-bottomed dish form and decoration. 


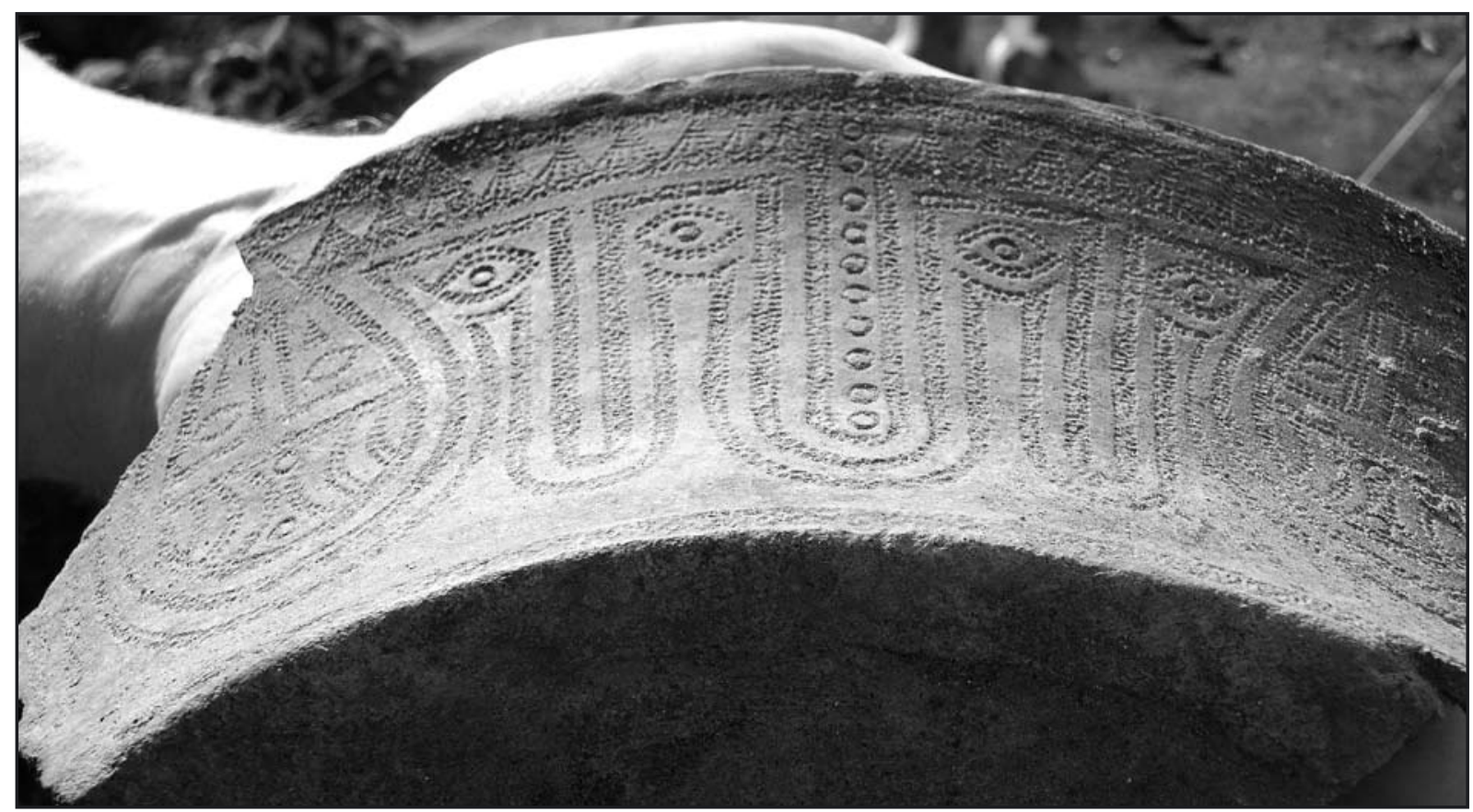

Figure 13. Joining point of double face motif on flat-bottomed dish.

\section{Plain pot stand}

Dimensions: Height: 90 mm, diameter top: 140 mm, diameter base: $190 \mathrm{~mm}$ (Figure 14).

We have tentatively labelled this almost complete vessel as a pot stand. It was found lying on its side, half buried in the upper most Lapita-associated occupation levels of the site. A number of burials were subsequently recorded in the near vicinity. Its hourglass form and wide rim and basal diameters indicate that it could have been used to support either flat or circular bottomed vessels. It is largely tubular apart from a solid section in the centre of the stand. There is no decoration evident on any part of the pot stand. It thus far appears to be a unique form although, as is so often the case, it would be very difficult to confidently assign small sherds to such a form.

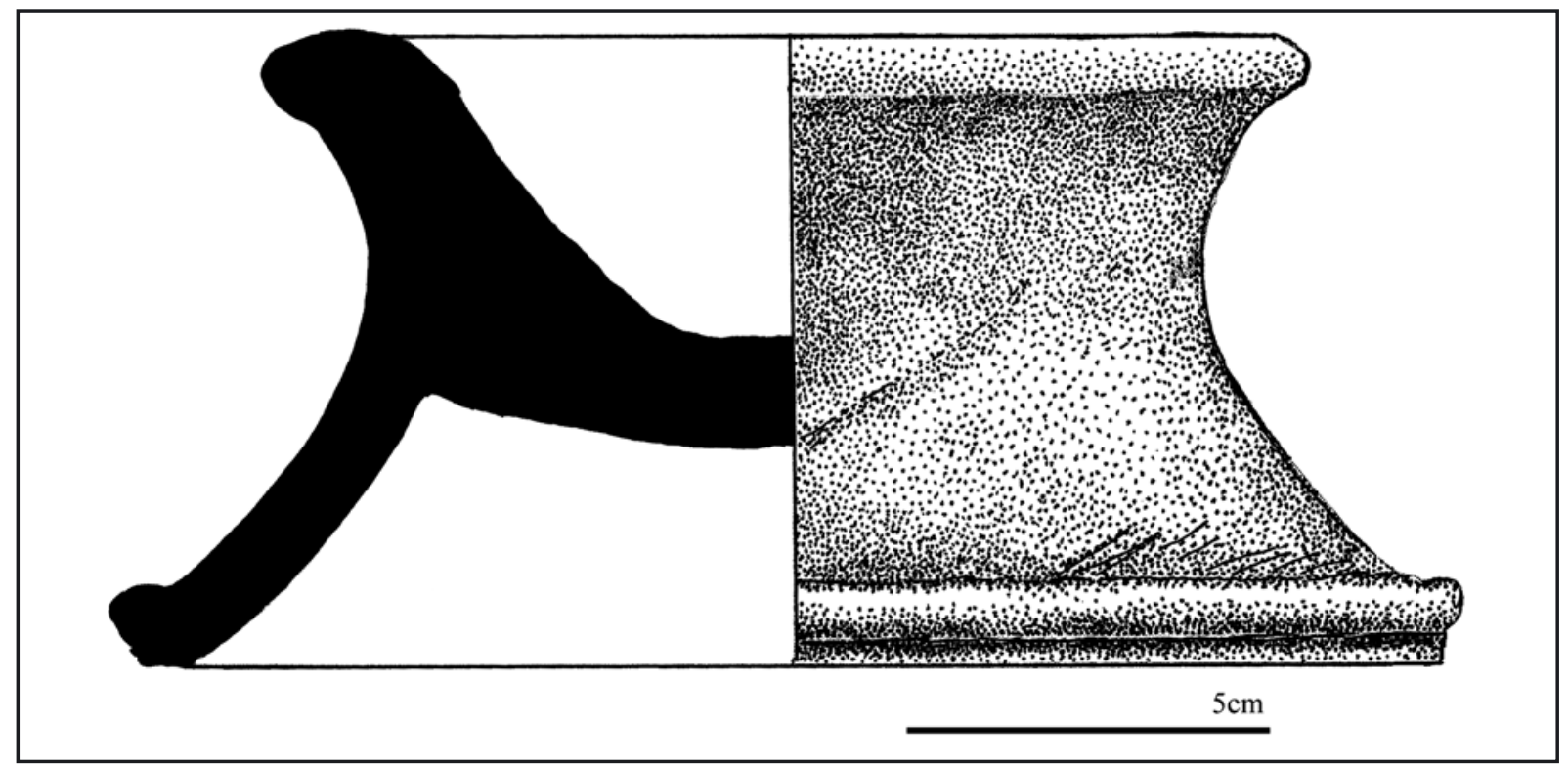

Figure 14. Plain pot stand form. 


\section{Conservation and reconstruction}

Five pots have been conserved and reconstructed at the Australian Museum in Sydney by the Collection Integrity Unit (Macgregor and Sietz 2006) and four have already been returned to the Vanuatu Cultural Centre. The pots each displayed different styles of form and decoration and the condition of the material varied. The reconstruction of each pot, therefore, presented different challenges. The overall techniques and materials applied, however, were the same for each pot. It is crucial that on-site lifting techniques of such pots are carefully considered and block lifting should only be chosen if there is a clear benefit to be had by supporting the pot as one piece with soil infill, until it reaches the lab. In the case of the Teouma pots the fragments needed to be dismantled anyway in order to clean edges and re-assemble the sherds. The procedure that was followed and deemed to be the most suitable in this case involved the careful mapping, lifting, bagging and packing of individual sherds.

Sherds that were surface collected during the initial reconnaissance to find the site in 2004 appeared robust and well preserved despite having been exposed during quarrying some four months previously. This suggested that soluble salts were not a major problem at Teouma as they had been at WKO013A Lapita (Coote and Sand 1999; Sand et al. 1998). If large amounts of soluble salts have accumulated in the fabric of the sherds, serious physical damage can occur post-excavation due to the recrystallisation of the salts following periods of high humidity (Cronyn 1990). The stability of the Teouma ceramics was further confirmed over the following twelve months as the surface collected and excavated sherds from the first season of fieldwork showed no sign of physical change. To verify this observation sherds from the complete vessels were tested for the presence of soluble salts. Fragments of the flat dish were soaked for two days in water and the conductivity of the bath was measured. The results were $9.5 \mu \mathrm{S}$ in the distilled water and $60 \mu \mathrm{S}$ after soaking the sherds. This moderate increase in conductivity indicates that there was not a significant amount of soluble salt in the fabric of the pots.

All sherds were initially dry brushed. This was the preferred method for cleaning the sherds as the fabric of some of the pots (Pots 2 and 3) would have been prone to disintegration if washed in water. Harder

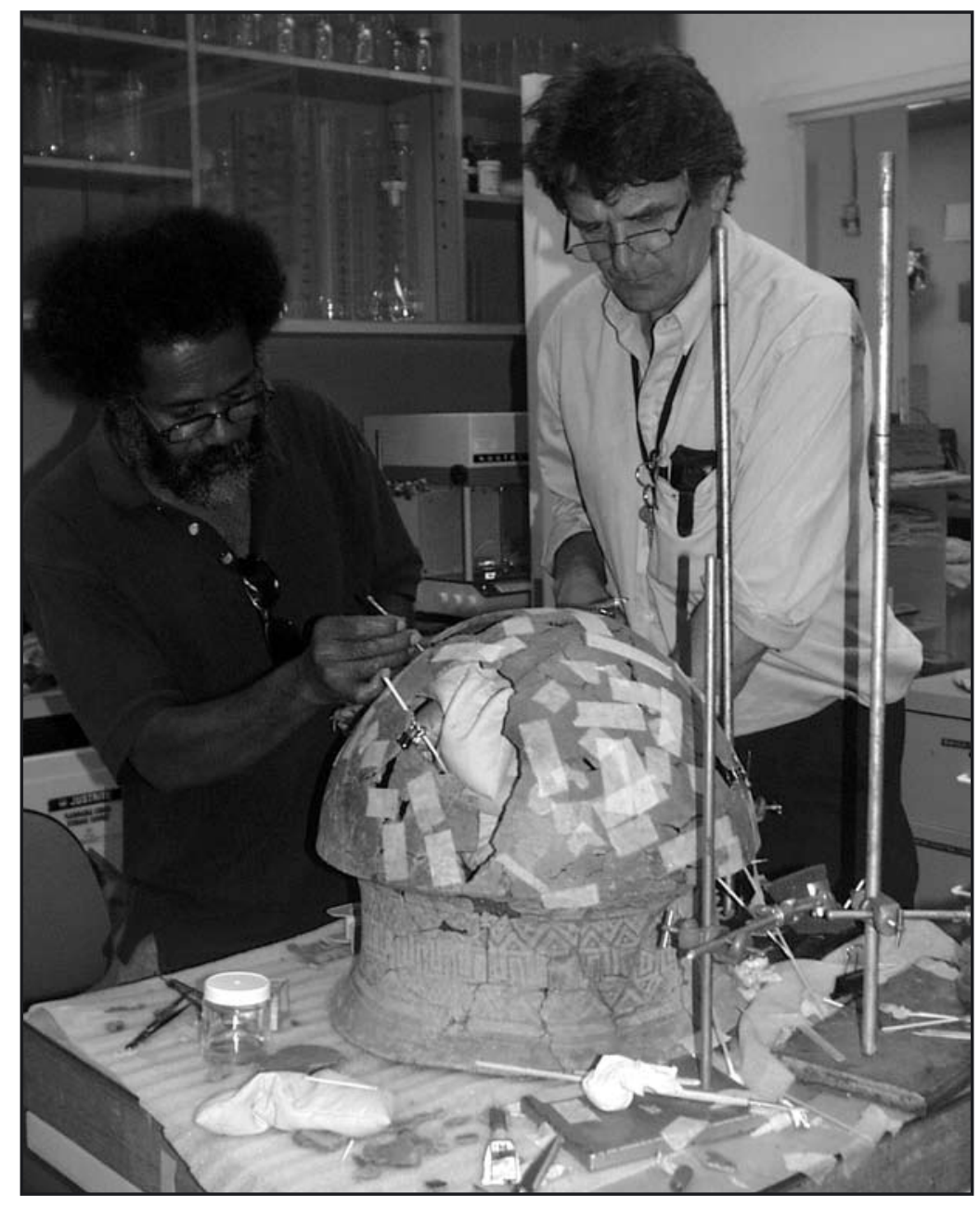

Figure 15. Takaronga Kuautonga and Colin Macgregor reconstructing Pot 3. Note small sand bag and structural supports. 
accretions were removed from the edges using scalpels where necessary. In general, there was a conscious effort to avoid over-cleaning of the internal and external surfaces to avoid impeding future analysis by removing trace residues that may be present. Prior to assembly the edges were consolidated by applying a thin solution of Paraloid B72 acrylic resin in acetone to the edges (Koob 1986). The concentration of the solution was varied between $5-10 \%$ depending on the porosity of the pot. The solution was applied with either a fine brush or a pipette. This localised consolidation strengthens the edges and prevents the adhesive migrating into the fabric during reconstruction. The condition of the pots did not warrant complete consolidation of the fabric by total immersion in solution. Total consolidation by immersion is sometimes necessary with pottery, due to its extremely friable nature caused by crushinga or salt damage.

The sherds were joined using a premixed Paraloid B72 adhesive, applied directly onto the broken edges or by injection into the gaps of the assembled edges. Surgical paper adhesive bandage tape was used to preassemble sections to ensure a good fit and also to secure the sherds in position whilst the adhesive hardened. In order to provide adequate strength in areas where the edges had eroded resulting in very narrow points of contact, a thickened paste of adhesive was applied consisting of a mixture of Paraloid B72 (30\%) in acetone and glass micro-balloons. This increased the contact area with the two surfaces considerably.

All three carinated pots were assembled upside down beginning with the decorated rim and neck sections. For Pots 2, 3 and 4, a wall of sand bags and PE-foam sheets was used to support the round bottom from inside (Figure 15). The carinated vessels also required areas of loss to be gap-filled with pigmented plaster. This was generally applied where required to provide enough strength for long-term stability. No decorations were imitated with the infillings. To protect the surface, areas along gaps are covered with liquid latex during the infilling process. The liquid plaster is supported from one side by a mould of plasticine or a thin sheet of PE-foam covered with foil. The final retouching of the colour to blend with the overall look of the pot was carried out using acrylic paints and added dry pigments.

\section{Discussion and Conclusion}

The discovery of well-preserved archaeological sites often injects a sudden burst of increased knowledge to areas of research that are more commonly assessed and profiled through the steady incremental accumulation of data. In the case of Lapita, and more specifically the characterisation of the distinctive decorated pots, a number of sites fall into this former category, namely the Arawes, Mussau, Reef-Santa Cruz, Site 13 at Lapita and Sigatoka. While Teouma can now be added to this list, the remains at the site also highlight the complexity found with even a well preserved archaeological record and the inherent difficulties in interpreting and explaining human behaviour and activity.

The cemetery at Teouma furnishes insights into the mortuary practices of the earliest Lapita settlers of Remote Oceania which appear to have been a multi-faceted and on-going process (Bedford et al. 2006). Certain aspects of the mortuary practices at Teouma, including the use of pots in burial ceremony have close parallels with mortuary practices in Island Southeast Asia, including Taiwan, during earlier and contemporary periods (Bellwood 1997). As long hypothesised, decorated pots clearly had a significant role in Lapita ceremonial activity (Kirch 1997), but as demonstrated in the case of the Teouma burials, there are both patterns and peculiarities in their use and function. All of the excavated reconstructed vessels, and almost certainly the carinated vessel retrieved during earthmoving, were associated with mortuary activity. There is no standard positioning or use of the pots. Pots were placed in upturned positions, others upright with assorted human bone deposited within them and in one case of clear secondary or even opportunistic use, a flat-bottomed dish was used as a lid. Carinated vessels dominate in the reconstructed sample as they do with the collection of less complete excavated sherds across the cemetery, but they vary greatly in size and in some aspects of their shape (Figure 16). The complete pots are all 


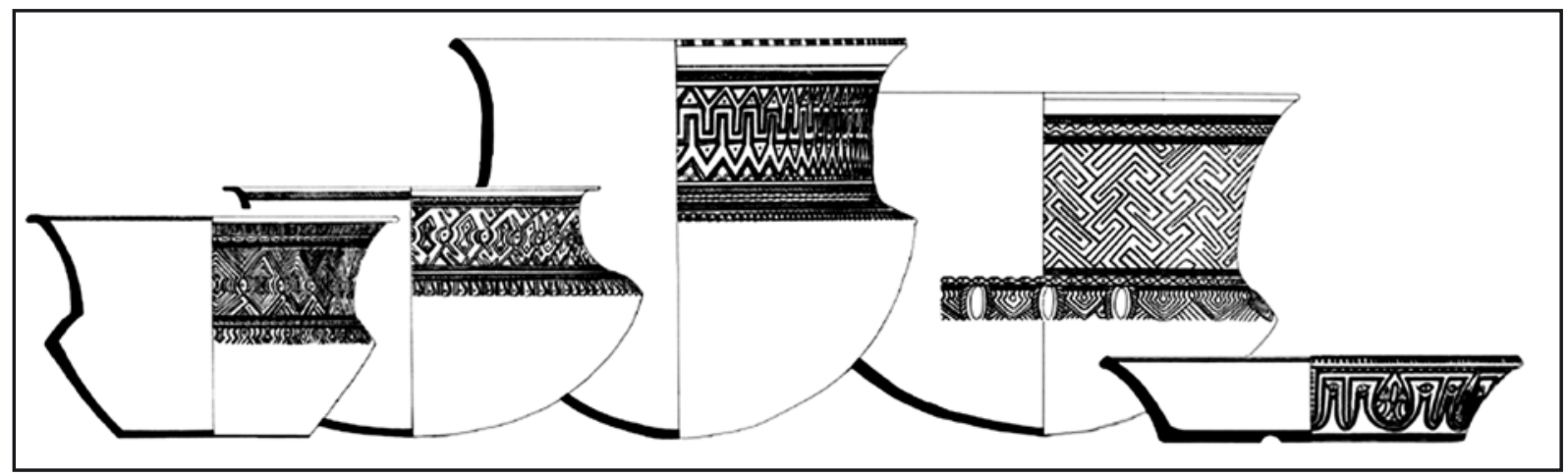

Figure 16. Broad relative size comparisons of the complete vessels. From left to right, Pot 1, 2, 3, 4 and flat dish.

decorated, although with a range of both fine and coarse dentate decoration, one with a face motif and the others with geometric designs. These features from Teouma underscore conclusions reached by other researchers in relation to gauging chronological variation in Lapita ceramics: that is that vessel form, decorative finesse, and design structure and content are not always a definitive marker of chronological divergence (Chiu 2005:27, this volume; Sand et al. 1998:41).

For a long time Lapita in Vanuatu has been somewhat of a confused picture, with only limited reporting being restricted to the mixed deposits from Malo (Hedrick 1971, nd; Hedrick and Shutler 1969) and the very limited numbers of sherds from Erueti on Efate (Garanger 1972: Fig. 9) and Erromango (Bedford 2006a:102). The recent discovery, however, of the well preserved sites of Makue on Aore (Galipaud 2001; Galipaud and SweteKelly this volume; Galipaud and Vienne 2005), sites on the small islands (Vao, Atchin, Wala and Uripiv) off the northeast coast of Malakula (Bedford 2003, 2006b) and Teouma are set to dramatically change the situation, particularly in terms of providing a robust profile of the Lapita ceramics of Vanuatu which is essential for inter-regional comparisons. As perhaps we should expect, none of the complete vessels from Teouma have direct parallels with any of the whole pots from New Caledonia, although many elements of the full designs are indeed present. Virtually all the motifs present on the Teouma pots can be found in the assemblages from the Reefs-Santa Cruz Group but this again might be expected as it is far easier to find direct parallels amongst single motifs from a large collection of fragmented sherds from several sites than a limited range of whole pots. What the growing corpus of complete design motifs is certainly highlighting, however, is the extensive range of motif permutations and combinations that were produced by Lapita potters. One of the more distinctive decorative features found on the complete pots from Teouma is the sets of applied vertical lugs or bars seen on Pot 4 (a feature that has also been found on Vao). This is a decorative feature not found thus far in sites further west or in New Caledonia but is found in modified form in both Fiji and Tonga (Davidson et al. 1990:Fig. 15; Poulsen 1987 Vol 2:145), hinting at potential Vanuatu origins or links.

Not all decorated Lapita pots were associated with burials but rather with a whole range of ceremonial activities (Clark and Murray 2006:114). The difficulty for archaeologists, however, is being able to identify these in the often very mixed and disturbed deposits that comprise most Lapita sites. The discovery of sites such as Teouma provides us with a rare opportunity to investigate Lapita mortuary ritual and establish a detailed profile of the associated pottery (cf. Clark and Wright in press). These data can then potentially be used to glean greater information and definition from the myriad of other excavated materials from Lapita sites which have not been so well preserved. 


\section{Acknowledgments}

The Teouma Archaeological Project is a joint initiative of the Vanuatu National Museum and The Australian National University (ANU), directed by Professor Matthew Spriggs and Dr Stuart Bedford of the ANU and Mr Ralph Regenvanu, Director of the Vanuatu Cultural Centre until December 2006. Funding of the project in 2004 and 2005 was provided by the Pacific Biological Foundation, The Royal Society of New Zealand (Marsden Fastart) and the Department of Archaeology and Natural History and School of Archaeology and Anthropology at the ANU. Excavations in 2006 were funded primarily through a National Geographic Society Scientific Research Grant with additional funding from the Australian Research Council (DP0556874). The drawing skills of Fidel Yoringmal were invaluable both in recording the pots on site and the illustration of the complete pots figured here. Thanks must also be extended to our collaborators in the field, Jacques Bolé, Hallie Buckley, Nancy Tayles, Willy Damelip, Stuart Hawkins, Andrew Hoffman and Frédérique Valentin. The support of the leaseholder Robert Monvoisin and family is acknowledged, as is the support and assistance of the traditional landowners of Eratap Village. Staff of the Vanuatu Cultural Centre were enthusiastic and supportive throughout. Conservation and reconstruction of the pots was primarily funded by the Australian Museum with additional funding from the International Council of Museums and AusAID which facilitated the participation of Takaronga Kuautonga, curator at the National Museum of Vanuatu. Photographs labelled Figures $7 \mathrm{~b}, 9$ and 10b were taken by Stephen Alvarez and permission for their reproduction was granted by the Picture Editor, National Geographic Magazine. Christophe Sand and Geoff Clark read earlier drafts of the paper and provided productive criticism.

\section{References}

Bedford, S. 2003. The timing and nature of Lapita colonisation in Vanuatu: the haze begins to clear. In C. Sand (ed.), Pacific Archaeology: assessments and prospects, pp. 147-158. Noumea: Les Cahiers de l'archéologie en Nouvelle-Calédonie 15.

Bedford, S. 2006a. Pieces of the Vanuatu Puzzle: Archaeology of the North, South and Centre. Canberra: Pandanus Press, Australian National University. Terra Australis 23.

Bedford, S. 2006b. The Pacific's earliest painted pottery: an added layer of intrigue to the Lapita debate and beyond. Antiquity 80:544-557.

Bedford, S., A. Hoffman, M. Kaltal, R. Regenvanu and R. Shing 2004. Dentate-stamped Lapita reappears on Efate, Central Vanuatu: a four decade-long drought is broken. Archaeology in New Zealand 47(1):39-49.

Bedford, S., M. Spriggs and R. Regenvanu 2006. The Teouma Lapita site and the early human settlement of the Pacific Islands. Antiquity 80:812-828.

Bedford, S. and M. Spriggs 2007. Birds on the rim: a unique Lapita carinated vessel in its wider context. Archaeology in Oceania 42:12-21.

Bedford, S. and M. Spriggs in prep. Lapita vessel form and decoration in Central Vanuatu: characterisation and comparison.

Bellwood, P. 1997. Prehistory of the Indo-Malaysian Archipelago. Honolulu: University of Hawaii Press.

Birks, L. 1973. Archaeological Excavations at Sigatoka Dune Site, Fiji. Suva: Bulletin of the Fiji Museum, No. 1.

Burley, D. and W. Dickinson 2004. Late Lapita occupation and its ceramic assemblage at the Sigatoka Sand Dune site, Fiji and their place in Oceanic prehistory. Archaeology in Oceania 39:12-25.

Chiu, S. 2005. Meanings of a Lapita Face: Materialized Social Memory in Ancient House Societies. Taiwan Journal of Anthropology 3:1-47. 
Coote, K. and C. Sand 1999. The conservation of Lapita pottery: ignore it at your peril. In J-C. Galipaud and I. Lilley (eds), The Western Pacific from 5000 to 2000 BP. Colonisation and transformations, pp. 333-343. Paris: IRD Éditions.

Clark, G. and T. Murray 2006. Decay characteristics of the eastern Lapita design system. Archaeology in Oceania 41:107-117.

Clark, G. and D. Wright in press. Reading Pacific Pots. In A. Anderson (ed.), Title TBA. Dunedin: University of Otago Press.

Cronyn, J. 1990 The elements of archaeological conservation. London: Routledge.

Davidson, J., E. Hinds, S. Holdaway and F. Leach 1990. The Lapita site of Natanuku, Fiji. New Zealand Journal of Archaeology 12:121-155.

Donovan, L. J. 1973. Inventory of Design Elements and Motifs in Lapita Reef-Santa Cruz Island Pottery. Unpublished appendices to MA research essay, University of Auckland.

Hedrick, J. 1971. Lapita Style Pottery from Malo Island. Journal of the Polynesian Society 80 (1):5-19.

Hedrick, J. nd. Archaeological Investigations of Malo Prehistory. Lapita Settlement Strategy in the Northern New Hebrides. Manuscript draft of PhD dissertation, University of Pennsylvania.

Hedrick, J. and M. E. Shutler 1969. Report on “Lapita Style” Pottery From Malo Island, Northern New Hebrides. Journal of the Polynesian Society 78 (2):262-65.

Kirch, P.V. 1997. The Lapita Peoples. Ancestors of the Oceanic World. Oxford: Blackwell.

Koob, S. 1986. The Use of Paraloid B72 as an adhesive: its application for archaeological ceramics. Studies in Conservation 31:7-13.

Macgregor, C. and M. Sietz 2006. The Conservation of Four Lapita Pots from the Teouma Excavations, Vanuatu. Unpublished report, Australian Museum.

Galipaud, J-C. 2001. Survey of Prehistoric Sites in Aore. Preliminary assessment. Unpublished report to Vanuatu Cultural Centre.

Galipaud, J-C. and B. Vienne. 2005. Chronologie du peuplement et réseaux d'échanges dans le nord du Vanuatu. Mission Santo 2005. Rapport préliminaire. Nouméa: IRD.

Garanger, J. 1972. Archéologie des Nouvelles-Hébrides: contribution à la connaissance des îles du centre. Publications de la Société des Océanistes, No.30. Paris: ORSTOM.

Poulsen, J. 1987. Early Tongan Prehistory. 2 Vols. Canberra: Department of Prehistory, Australian National University. Terra Australis 12

Sand, C. 1996. Intervention d'urgence sur le site WKO013A de lapita octobre 1995. Noumea: Départment Archéologie du Service des Musées et du Patrimoine de Nouvelle-Calédonie .

Sand, C. 1999. Lapita. The pottery collection from the site at Foué, New Caledonia. Noumea: Les cahiers de l'archéologie en Nouvelle-Calédonie, Volume 7.

Sand, C. 2000. The specificities of the "Southern Lapita Province": the New Caledonian case. Archaeology in Oceania 35(1):20-33.

Sand, C., K. Coote, J. Bole and A. Ouetcho 1998. A pottery pit at locality WKO013A, Lapita (New Caledonia). Archaeology in Oceania 33:37-43.

Spriggs, M. 1990. The Changing face of Lapita: the transformation of a design. In M.T. Spriggs (ed.), Lapita design, form and composition: proceedings of the Lapita design workshop, Canberra, Australia, December 1988, pp.83-122. Canberra: Department of Prehistory, Australian National University. Occasional Papers in Prehistory 18.

Spriggs, M. 1993. How Much of the Lapita Design System Represents the Human Face? In P. Dark and R. Rose (eds), Artistic Heritage in a Changing Pacific, pp.7-14. Bathurst: Crawford House Press

Spriggs, M. 2002. They've grown accustomed to your face. In Bedford, S., C. Sand and D. Burley (eds), Fifty Years in the Field: Essays in Honour and Celebration of Richard Shutler Jrs Archaeological Career, pp.51-58. Auckland: New Zealand Archaeological Association Monograph 25. 